\title{
COMPLICATIONS AFTER HIP DISARTICULATION AND HEMIPELVECTOMY
}

\author{
Stanislav Rajković ${ }^{1}$, Nikica Mandić1, Nenad Lujić1, Zoran Vučinić́1, Danilo Jeremić1
}

${ }^{1}$ Institut za ortopediju „Banjica”, Beograd, Srbija

\author{
${ }^{1}$ Institute for Orthopedic Surgery "Banjica", Belgrade, Serbia
}

\section{SAŽETAK}

Uvod: Dezartikulacija kuka i hemipelvektomija su hirurške procedure sa visokom učestalošću lokalnih komplikacija: otok skrotuma/labija, površinska nekroza, infekcija i dehiscencija rane.

Cilj: Prikazujemo lokalne komplikacije u našoj seriji.

Materijal i metode: U studiju je uključeno 17 pacijenata; 16 sa malignim tumorom i jedan sa osteomijelitisom. Dvanaest tumora su bili tumori mekog tkiva, a četiri tumora su bili maligni tumori kosti. Korišćene deskriptivne statističke metode i metode za testiranje hipoteze bile su: srednja vrednost, standardna devijacija i apsolutni brojevi kao indikatori strukture, t-test i Fišerov test.

Rezultati: Lokalne komplikacije su utvrđene kod deset pacijenata. Edem skrotu$\mathrm{ma} /$ labija je utvrđen u pet slučajeva, površinska nekroza u četiri, infekcija rane u šest, i dehiscencija rane u sedam slučajeva. Pojedinačne komplikacije su utvrđene kod tri pacijenta. Dve i tri komplikacije u po tri slučaja, a četiri kod jednog pacijenta. Nije utvrđena značajna statistička razlika između muškaraca ižena $(p=1,000)$. Pacijenti sa komplikacijama su bili značajno stariji $(p=0,008)$. Korelacija je utvrđena jedino između infekcije i dehiscencije rane $(p=0,001)$. Staphylococcus aureus je pronađen u tri slučaja, Enterococcus faecalis u jednom, Pseudomonas aeruginosa u tri, Proteus mirabilis u dva i Acinetobacter spp. u jednom slučaju. Dva pacijenta su imala infekciju jednim agensom, ostala četiri su imala polimikrobnu infekciju. Učestalost komplikacija je bila 58,8\%, a infekcija rane je bila najčěćć. Starosna dob je utvrđena kao mogući prediktivni faktor. Ovo bi moglo biti povezano sa stanjem krvnih sudova i sa opštim stanjem.

Zaključak: Komplikacije u dezartikulaciji kuka/hemipelvektomiji variraju od beznačajnih do životno ugrožavajućih, i one produžavaju oporavak i rehabilitaciju.

Ključne reči: dehiscencija, infekcija, tumor

\begin{abstract}
Introduction: Hip disarticulation and hemipelvectomy are surgical procedures with a high rate of local complications: swollen scrotum/labia, superficial necrosis, infection, and wound dehiscence.

Aim: We present local complications in our series.

Material and methods: 17 patients were included in the study, there were 16 cases of malignant tumors and one case of osteomyelitis. Twelve of the tumors were soft tissue tumors, and four were malignant bone tumors. The descriptive statistical methods and methods for hypothesis testing used were the following: mean value, standard deviation and absolute numbers as structure indicators, the t-test, and Fisher's exact test.
\end{abstract}

Results: Local complications were observed in ten patients. Scrotum/labia edema was observed in five, superficial necrosis in four, wound infection in six and wound dehiscence in seven cases. A single complication was observed in three patients; two and three complications were observed in three cases, each; and four complications were observed in one patient. No significant statistical difference was found between male and female patients $(p=1.000)$. Patients with complications were significantly older $(p=0.008)$. Correlation was found only between wound infection and dehiscence $(p=0.001)$. Staphylococcus aureus was found in three cases, Enterococcus faecalis in one, Pseudomonas aeruginosa in three, Proteus mirabilis in two and Acinetobacter spp. in one. Two patients had a single agent infection, the remaining four had polymicrobial infection.

The complication rate was $58.8 \%$, with wound infection being the most common one. Age was found as a possible predictor. This might be in relation to the condition of the blood vessels, but also with the general condition of the patient.

Conclusion: Complications in hip disarticulation/hemipelvectomy vary from insignificant to life threatening, prolonging recovery and rehabilitation.

Keywords: dehiscence, infection, tumor
Autor za korespondenciju:

Stanislav Rajković

Institut za ortopediju „Banjica”

Mihaila Avramovica 28, 11000 Beograd, Srbija

Elektronska adresa: stanislav.rajkovic@iohbb.edu.rs,

stanbgd@hotmail.com

Primljen • Received: October 24, 2020; Revidiran • Revised: November 10, 2020; $\quad$ Prihvaćen • Accepted: December 9, 2020;

Online first: December 25, 2020. 


\section{UVOD}

Dezartikulacija kuka i hemipelvektomija su hirurške tehnike amputacije noge kroz zglob kuka ili kroz karličnu kost, što uključuje uklanjanje acetabuluma zajedno sa ostatkom noge. Obe spadaju među najradikalnije hirurške intervencije, ne samo u ortopediji već i u hirurgiji uopšte [1].

Najčešće indikacije za ove procedure su neresektabilni muskuloskeletni maligni tumori, ishemija ekstremiteta i teška trauma [2]. Dezartikulacija kuka usled inficiranog donjeg ekstremiteta se u današnje vreme ne izvodi često, ali u slučajevima gangrene, nekrotizirajućeg fasciitisa, infekcije nastale nakon artroplastike kuka, osteomijelitisa proksimalnog femura, inficiranih vaskularnih transplantata, i teških dekubitalnih ulceracija kod paraplegičara, to je još uvek procedura prvog izbora [3]. U najvećem broju ovih slučajeva prisutno je oboljenje koje zahvata i kost i meka tkiva u butini, naročito neurovaskularnu peteljku ili nerv išijadikus, ili oba. Hemipelvektomija je indikovana u slučajevima gde tumor ili oboljenje obuhvataju zglob kuka ili karlicu [4].

Budući da je ovo toliko radikalna procedura, ovu vrstu intervencije prati stopa perioperativnog mortaliteta od $0 \%$ do čak 37\% [5]. Ovi kontroverzni rezultati po pitanju mortaliteta variraju u zavisnosti od indikacija, kliničkog statusa pacijenta, i stepena hitnosti operacije. Planiranim operacijama ostvaruju se najbolji rezultati, pogotovo u slučajevima tumora. Nasuprot tome, najslabiji rezultati se beleže kod teških politraumatizovanih pacijenata, što se dovodi u vezu sa hemodinamskom nestabilnošću. [6].

Beleži se visoka stopa komplikacija od oko $65 \%$ [5, 6]. Opisane su različite lokalne komplikacije: otok skrotuma ili labija, površinska nekroza, infekcija i dehiscencija rane [7]. U mnogim opisanim slučajevima prisutno je više od jedne komplikacije.

Cilj ove retrospektivne studije jeste predstavljanje lokalnih komplikacija u našoj seriji.

\section{MATERIJAL | METODE}

Studija je uključivala 17 pacijenata podvrgnutih dezartikulaciji kuka ili hemipelvektomiji tokom dvogodišnjeg perioda. Ukupno je bilo 10 pacijenata muškog pola i 7 ženskog pola, starosne dobi od 19 do 78 godina (srednja vrednost 56). Osim jednog, svi pacijenti su imali maligne tumore, a jedan je bio slučaj teškog hroničnog osteomijelitisa femura. U 12 slučajeva, u pitanju je bio tumor mekih tkiva (svi visoko gradusni maligni), a kod četiri slučaja u pitanju su bili maligni tumori kostiju.

Korišćene deskriptivne statističke metode bile su mere centralne tendencije (srednja vrednost), mere varijabilnosti (standardna devijacija) i apsolutni brojevi (indikatori strukture). Metode za testiranje hipoteze

\section{INTRODUCTION}

Hip disarticulation and hemipelvectomy are surgical techniques of leg amputation, through the hip joint or through the pelvic bone, which entail removing the acetabulum along with the rest of the leg. Both are some of the most radical surgical procedures, not only in orthopedic, but in surgery in general [1].

The most common indications for these procedures are unresectable musculoskeletal malignant tumors, limb ischemia, and severe trauma [2]. Disarticulation of the hip due to an infected lower extremity in this day and age is not performed often, but in cases of gangrene, necrotizing fasciitis, infection following hip arthroplasty, proximal femur osteomyelitis, infected vascular grafts, and severe decubitus ulcers in paraplegics, it is still the procedure of choice [3]. In most of these cases there is a disease involving both bone and soft tissue in the thigh, especially the neurovascular bundle or the sciatic nerve, or both. Hindquarter amputation is indicated in cases where a tumor or disease process involve the hip joint or pelvis. [4].

As it is so radical, this procedure is followed by a perioperative mortality rate ranging from $0 \%$ up to as much as 37\% [5]. These controversial results regarding mortality vary depending on the indication, clinical status of the patient, and the degree of urgency of the surgery. Elective surgery is followed by the best results, particularly in tumor cases. Conversely, the worst results are noted in severe polytrauma patients, associated with hemodynamic instability [6].

A high rate of complications of around $65 \%$ has been noted $[5,6]$. Different local complications have been described: swollen scrotum or labia, superficial necrosis, infection, and wound dehiscence [7]. In many described cases more than one complication was present.

The aim of this retrospective study is to present local complications in our series.

\section{MATERIALS AND METHODS}

The study included 17 patients who had undergone hip disarticulation or hemipelvectomy during a twoyear period. There were 10 male and 7 female patients, ranging from 19 to 78 years of age (mean 56). All, but one, were malignant tumor patients and one was a case of severe chronic femur osteomyelitis. There were 12 cases of soft tissue tumors (all high-grade malignant) and four cases of malignant bone tumors.

The descriptive statistical methods used were measures of central tendency (mean value), variability measures (standard deviation) and absolute numbers (structure indicators). The methods used for hypothesis testing were the t-test and Fisher's exact test (with Holm adjustments for multiple comparisons). 


\begin{tabular}{|c|c|c|c|c|c|c|c|c|}
\hline ID /ID & Pol/Gender & Starost/Age & Indikacija/Indication & Tumor/Tumor & \multicolumn{4}{|c|}{ Vrsta komplikacije / Type of complications } \\
\hline 1 & $\mathrm{~m} / \mathrm{m}$ & 44 & TU & ST & & & & \\
\hline 2 & $\mathrm{~m} / \mathrm{m}$ & 48 & TU & ST & 0 & & & \\
\hline 3 & $\mathrm{~m} / \mathrm{m}$ & 58 & TU & ST & 0 & & & \\
\hline 4 & $\mathrm{~m} / \mathrm{m}$ & 56 & TU & ST & & $\mathrm{N}$ & I & D \\
\hline 5 & $\mathrm{~m} / \mathrm{m}$ & 19 & TU & BT & & & & \\
\hline 6 & $\mathrm{~m} / \mathrm{m}$ & 41 & TU & ST & & & & \\
\hline 7 & $\mathrm{~m} / \mathrm{m}$ & 69 & TU & BT & & N & & D \\
\hline 8 & $\mathrm{~m} / \mathrm{m}$ & 56 & TU & ST & & & & \\
\hline 9 & $\mathrm{~m} / \mathrm{m}$ & 72 & TU & ST & & & I & D \\
\hline 10 & $\mathrm{~m} / \mathrm{m}$ & 67 & TU & BT & & $\mathrm{N}$ & & \\
\hline 11 & $\check{z} / f$ & 43 & TU & BT & & & & \\
\hline 12 & ž /f & 57 & TU & ST & 0 & & I & D \\
\hline 13 & $\check{z} / f$ & 65 & TU & ST & & & I & $D$ \\
\hline 14 & ž/f & 78 & $0 \mathrm{M}$ & & 0 & $\mathrm{~N}$ & I & $D$ \\
\hline 15 & $\check{z} / f$ & 60 & TU & ST & & & & \\
\hline 16 & $\check{z} / f$ & 62 & TU & ST & 0 & & I & D \\
\hline 17 & $f$ & 59 & TU & ST & & & & \\
\hline
\end{tabular}

TU - tumor, OM - osteomijelitis, MT - tumor mekog tkiva, KT - tumor kosti, O- otok skrotuma/labija, N - nekroza, I - infekcija, D - dehiscencija

bile su t-test i Fišerov egzaktni test (uz Holmova podešavanja za višestruka poređenja).

\section{REZULTATI}

Lokalne komplikacije uočene su kod 10 pacijenata. Edem skrotuma ili labija uočen je kod 5 pacijenata, površinska nekroza kod četiri, infekcija rane kod 6 i dehiscencija rane kod 7 pacijenata. Bilo je dve odnosno tri komplikacije u po tri slučaja, te četiri komplikacije kod jednog pacijenta.

Tabela 2. Uzročnici infekcija
TU - tumor, OM - osteomyelitis, ST - soft tissue tumor, BT - bone tumor, 0 - scrotal/labial edema, $\mathrm{N}$ - necrosis, I - infection, D - dehiscence

\section{RESULTS}

Local complications were observed in 10 patients. Scrotal or labial edema was observed in 5 , superficial necrosis in four, wound infection in 6 and wound dehiscence in 7 cases. There were two and three complications, in three cases each, and four complications in one patient.

Six out of 10 male patients and four out of 7 female patients had complications, with no significant statistical difference $(p=1.000)$ with respect to gender. The

Table 2. Infectious agents

\begin{tabular}{|cc|}
\hline Infektivni agensi / Infectious agents & br. /n \\
\hline Monomikrobna infekcija / Monomicrobial infection & 1 \\
\hline Staphylococcus aureus & 1 \\
\hline Pseudomonas aeruginosa & 1 \\
\hline Polimikrobna infekcija / Polymicrobial infection & 1 \\
\hline Staphylococcu aureus + Pseudomonas aeruginosa & 1 \\
\hline Staphylococcus aureus + Enterococcus faecalis & 1 \\
\hline Pseudomonas aeruginosa + Proteus mirabilis & 1 \\
\hline Proteus mirabilis + Acinetobacter spp. & 1 \\
\hline
\end{tabular}


Komplikacije je imalo 6 od 10 muških i četiri od 7 sedam ženskih pacijenata, bez statistički značajne razlike u pogledu pola $(p=1,000)$. Srednja vrednost starosne dobi kod pacijenata sa komplikacijama bila je $63,2 \pm 8,8$ godina, a kod pacijenata bez komplikacija iznosila je 46,0 $\pm 14,3$. Pacijenti sa komplikacijama bili su značajno stariji $(p=0,008)$.

Nije utvrđena korelacija između komplikacija, osim između infekcije i dehiscencije rane, gde je korelacija imala visoku statističku značajnost $(p=0,001)$.

Infektivni agensi bili su sledeći: Staphylococcus aureus u tri slučaja, Enterococcus faecalis u jednom, Pseudomonas aeruginosa u tri, Proteus mirabilis u dva, i Acinetobacter spp. u jednom slučaju. Dva pacijenta su imala jednog uzročnika infekcije, preostala četiri su imala polimikrobne infekcije.

\section{DISKUSIJA}

Broj radova koji se bave ovom vrstom hirurških intervencija nije velik, pogotovo kada je u pitanju detaljan prikaz komplikacija. Međutim, u skoro svakom od postojećih radova prijavljena je visoka incidenca komplikacija. U svojoj seriji, koja je uključivala 53 pacijenta, Endin i saradnici [5] su utvrdili stopu komplikacija od $60 \%$, najčešće u vezi sa prethodnom infekcijom na mestu intervencije (osteomijelitis, septički artritis). Najčešći tipovi komplikacija bili su nekroza i infekcija rane.

U svojoj studiji, Degler i saradnici [8] su ispitivali samo onkološke pacijente i utvrdili stopu komplikacija od 44\%. Registrovali su nekrozu kožnog režnja kao najčešću komplikaciju (20\%), sledila ju je infekcija rane (16\%), zatim hematom, serom i dehiscencija rane (4\%). Ustanovili su i jednu herniju na mestu kuka nakon dezartikulacije. U drugim studijama su kao komplikacije utvrđene obturatorne hernije. Bile su uzrokovane jatrogenim anatomskim alteracijama koje su dovele do potencijalno životno ugrožavajućeg uklještenja hernije, usled čega je od suštinskog značaja da se u ovakvim slučajevima uspostavi tačna dijagnoza i defekt otkloni kao urgentno stanje [9].

Najobuhvatniji rad na ovu temu jeste studija Senčenkova i saradnika [10]. Uključivala je 160 pacijenata. Vodeći uzrok morbiditeta bila je infekcija rane, kod 39\% pacijenata, a sledila ju je dehiscencija, koja se javila u $26 \%$ slučajeva. Autori su istražili različite faktore koji bi u tom smislu mogli imati uticaja - starost, pol, pušenje, dijabetes, gojaznost, preoperativna terapija zračenjem, hemoterapija, ASA klasifikacija fizičkog stanja, tip i opsežnost hemipelvektomije, sami kožni režnjevi, dužina trajanja hirurške intervencije, i transfuzija krvi. Utvrđeno je da su samo dužina trajanja operativnog zahvata i opsežnost hemipelvektomije bili statistički značajni prediktori infekcije rane i problema sa njenim mean age in patients with complications was $63.2 \pm$ 8.8 years, and in patients without complications it was $46.0 \pm 14.3$. Patients with complications were significantly older $(p=0.008)$.

No correlation was found between complications except between wound infection and dehiscence, where correlation was highly statistically significant $(p=0.001)$.

The infectious agents were as follows: Staphylococcus aureus in three cases, Enterococcus faecalis in one, Pseudomonas aeruginosa in three, Proteus mirabilis in two and Acinetobacter spp. in one case. Two patients had a single agent infection, the remaining four had polymicrobial infection.

\section{DISCUSSION}

Not many papers deal with this type of surgery, especially when it comes to the details of its complications. However, almost all of them have reported a high incidence of complications. In their series involving 53 patients, Endean et al. [5] found a $60 \%$ complication rate, most commonly associated with previous site infection (osteomyelitis, septic arthritis). The most common types of complication were necrosis and wound infection.

In their study, Daigeler et al. [8] reviewed only oncological patients, and found a complication rate of $44 \%$. They noted flap necrosis as the most common (20\%), followed by wound infection (16\%), hematoma, seroma and wound dehiscence (4\%). They also found one hip hernia after hip disarticulation. In other studies, obturator hernias were found as complications. They were caused by iatrogenic anatomic alteration leading to possible life-threatening hernia incarceration, which makes it essential to make an accurate diagnosis and repair the defect as an emergency [9].

The most comprehensive paper on this subject is the one by Senchenkov et al. [10]. Their study included 160 patients. Wound infection was the leading cause of morbidity, in $39 \%$ of patients, followed by $26 \%$ of cases with dehiscence. The authors investigated different factors which could influence this - age, sex, smoking, diabetes, obesity, preoperative radiation therapy, chemotherapy, ASA physical status classification, the type and extent of hemipelvectomy, the flaps, the operation duration, and blood transfusion. Only the operation duration and the extent of hemipelvectomy were found to be statistically significant predictors of wound infection and healing problems. Other studies $[11,12,13]$ indicate that the surgical technique is of great importance for the outcome of this procedure. The separation of the m. gluteus maximus from the fasciocutaneous flap and extensive blood vessel ligation 
zarastanjem. Druge studije $[11,12,13]$ ukazuju na to da je hirurška tehnika od velikog značaja za ishod ovog zahvata. Odvajanje m. gluteus maximus-a od fasciokutanog režnja i ekstenzivno podvezivanje krvnih sudova značajno je koreliralo sa gubitkom režnja. Veličina režnja kao i temeljna postoperativna nega rane su od velikog značaja za pravilnu dezartikulaciju kuka [14]. Određeni radovi navode starost pacijenta od preko 65 godina i slabije imovinsko stanje kao moguće prediktore za razvoj komplikacija [15].

Slični rezultati dobijeni su i u našoj studiji. Stopa komplikacija bila je 58,8\%, pri čemu je dehiscencija rane bila najčešća. Registrovali smo slučajeve pacijenata sa površinskom nekrozom ali bez dehiscencije ili infekcije kao i slučajeve sa dehiscencijom bez infekcije, zbog čega smo odlučili da razdvojimo ove komplikacije. Nakon toga su dve najčešće komplikacije pronađene zajedno, pri čemu je infekcija prethodila dehiscenciji. Nije utvrđena korelacija između drugih komplikacija, tako da možemo reći da pojava edema skrotuma ili labija odnosno nekroze nije nužno znak infekcije ili nastupajuće dehiscencije. Sa druge strane, u slučaju pojave infekcije, sigurno je da će doći do razvoja dehiscencije u narednih nekoliko dana.

Utvrđeno je da je starosna dob mogući prediktor. Ovo može biti u vezi sa stanjem krvnih sudova, ali i sa opštim stanjem pacijenta. Mlađi pacijenti se oporavljaju brže, kreću se pomoću štaka i koriste toalet. Stariji pacijenti duže ostaju vezani za krevet, ne koristeći toalet, pa je stoga lokalna higijena lošija nego kod mlađih pacijenata kojima je izvršen ovaj zahvat, što je mogući faktor koji doprinosi razvoju infekcije.

U našoj studiji, utvrdili smo dve monomikrobne i četiri polimikrobne infekcije. Na ovu temu objavljeni su različiti rezultati, od kojih neki navode

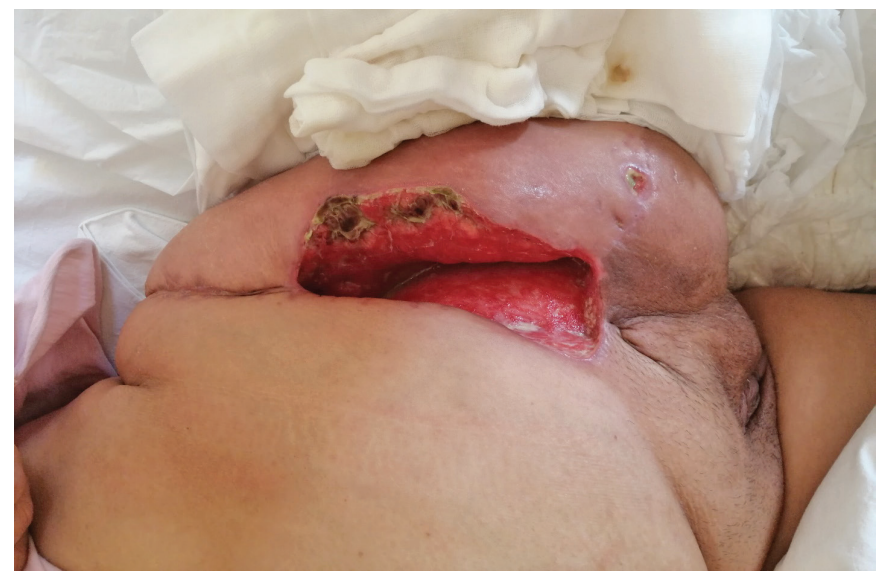

Slika 1. Dehiscencija rane nakon površinske nekroze. Neka polja nekroze i dalje vidljiva

Figure 1. Wound dehiscence after superfitial necrosis. Some fields of necrosis still visible was significantly correlated with loss of the flap. Flap size and thorough postoperative wound care are of high importance for proper hip disarticulation [14]. Certain papers note patient age of over 65 years and a lower economic status as possible predictors for the development of complications [15].

Similar results were found in our study. The complication rate was $58.8 \%$, with wound dehiscence as the most common one. We recorded patients with superficial necrosis but without dehiscence or infection and those with dehiscence without infection, which is why we decided to separate these complications. Later, the two most common complications were found together, with infection preceding dehiscence. No correlation was found between other complications, so we may say that if scrotal/labial edema or necrosis is present this is not necessarily a sign of infection or impending dehiscence. On the other hand, if an infection is present, it is certain that dehiscence will develop in a matter of days.

Age was found as a possible predictor. This might be in relation to the condition of the blood vessels, but also in relation to the general status of the patient. Younger patients tend to recover faster, ambulating with crutches and using the toilet. Elderly patients stay in bed longer, not using the toilet, so local hygiene is poorer than in their younger counterparts, which is possibly a factor in infection development.

In our study, we found two monomicrobial and four polymicrobial infections. Different results have been published on this matter, some stating monomicrobial infection as more common [16]. Staphylococcus aureus was found as the most common, followed by Pseudomonas aeruginosa and Proteus mirabilis, but other microorganisms were also found. Further investigation

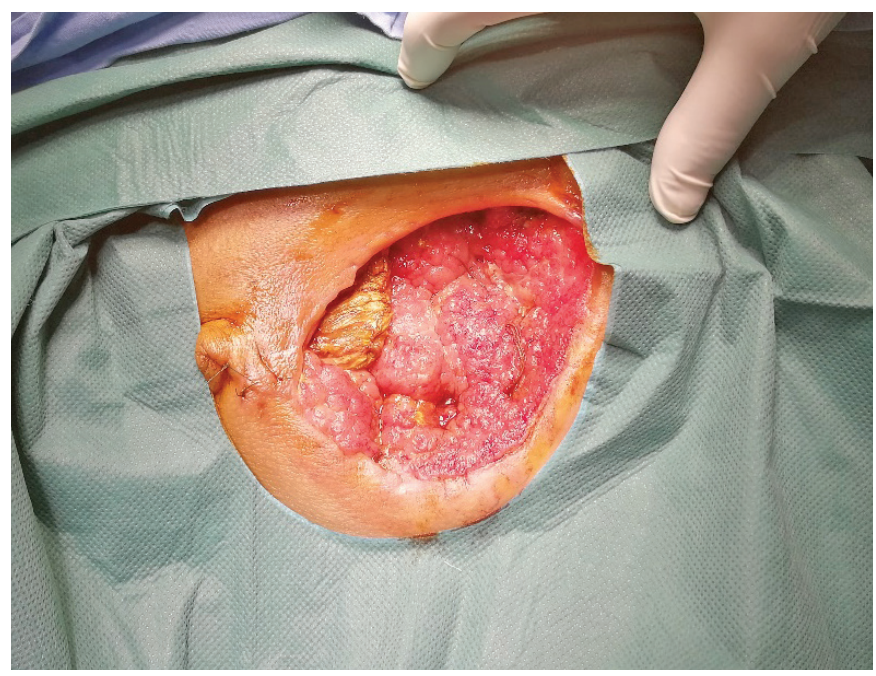

Slika 2. Hirurški debridman nekroze i vezivnog tkiva

Figure 2. Surgical debridement of necrosis and fibrotic tissue 


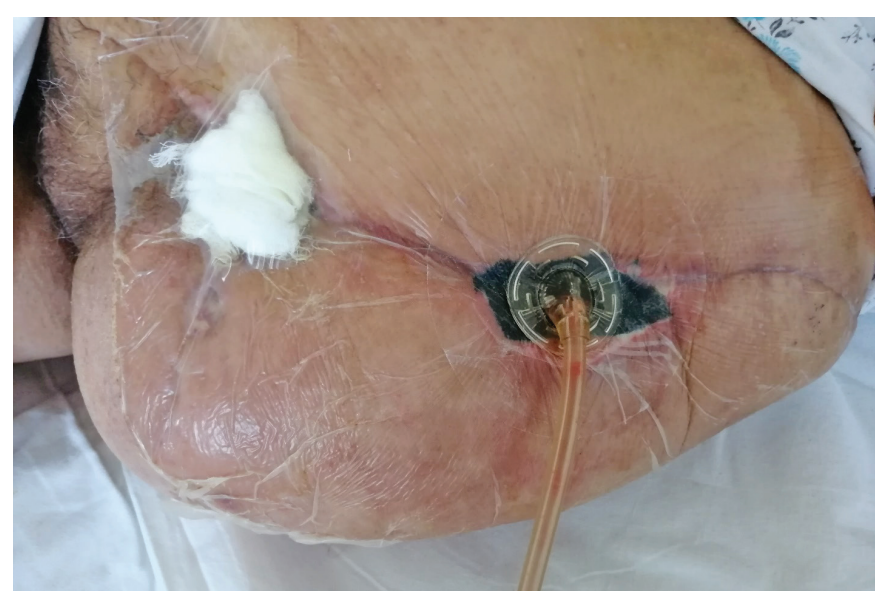

Slika 3. Početno zatvaranje rane vakuum sukcijom

Figure 3. Initial wound closure by vaccum suction

monomikrobnu infekciju kao češću [16]. Utvrđena je, kao najčešća, infekcija Staphylococcus aureus-om, potom slede Pseudomonas aeruginosa i Proteus mirabilis, ali su pronađeni i drugi mikroorganizmi. $U$ tom smislu, potrebna su dalja istraživanja kojima bi se utvrdilo da li jedan ili više agenasa ili određena vrsta agensa možda korelira sa težinom lokalnih komplikacija. U lečenju komplikacija, važno je naglasiti značaj sledećih faktora: ciljane antibiotske terapije zasnovane na rezultatima mikrobioloških analiza, nege rane usmerene na sprečavanje kontaminacije bolničkih infekcija, i saradnje između ortopeda-hirurga, mikrobiologa, anesteziologa, specijaliste za ishranu i rehabilitaciju i medicinskog osoblja [17].

U našoj seriji, svi pacijenti sa dehiscencijom rane su tretirani hirurški, neki i više puta. U nekim slučajevima,

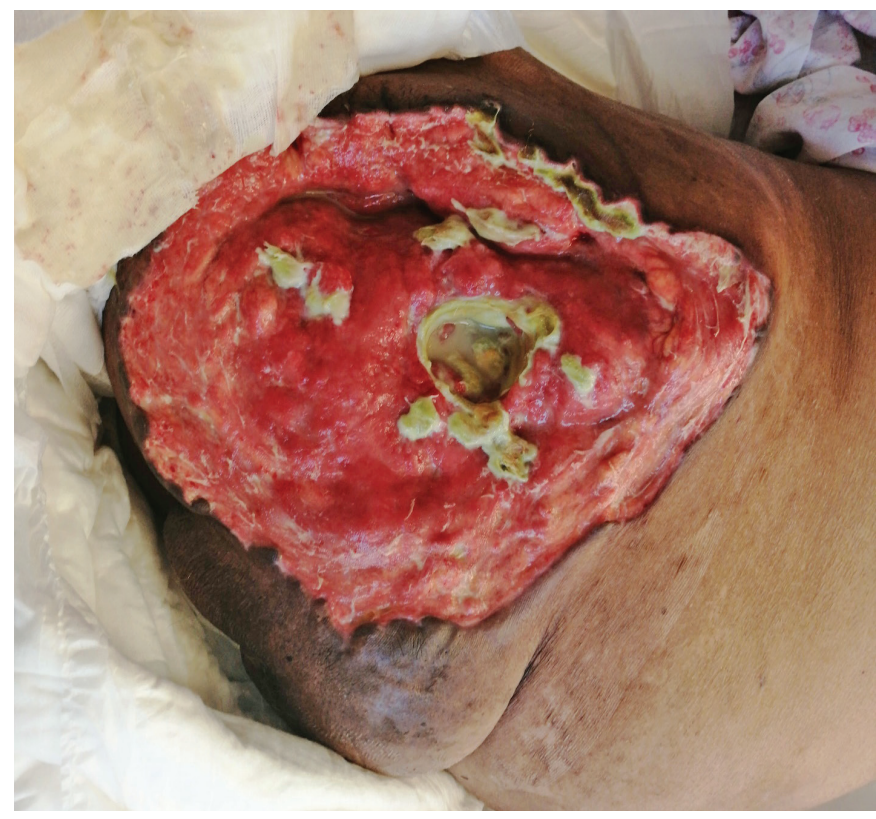

Slika 4. Potpuna dehiscencija rane sa infekcijom

Figure 4. Total wound dehiscence with infection should be undertaken with respect to this matter exploring whether one or more agents or a particular type of agent may be correlated with the severity of local complications. In the treatment of complications, it is important to emphasize the importance of the following: targeted antibiotic therapy based on microbiology examination results, wound management aimed at preventing contamination with intrahospital germs, and the cooperation between the orthopedic surgeon the microbiologist, the anesthesiologist, the nutrition and rehabilitation specialist and the nursing staff [17].

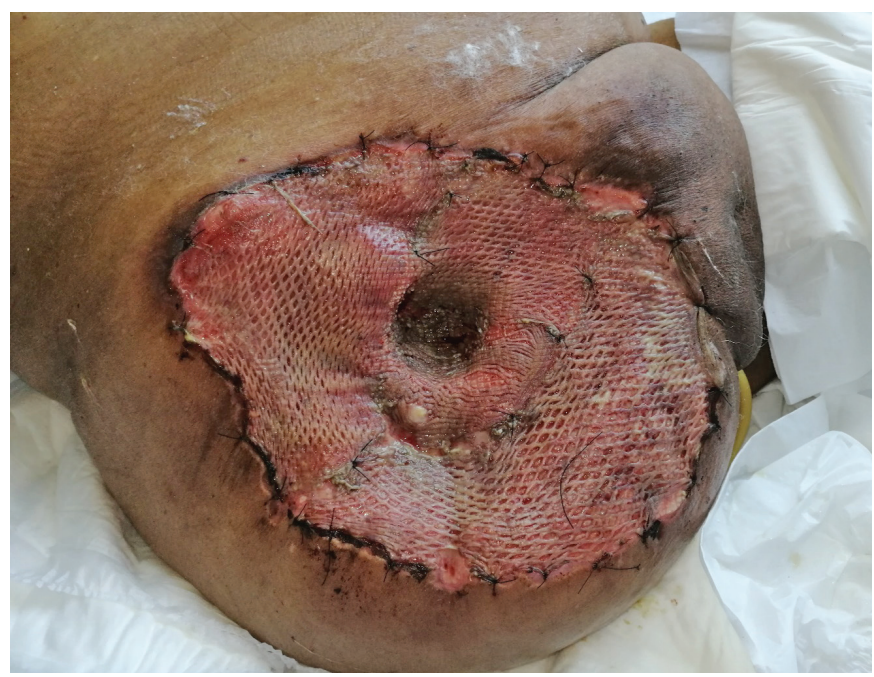

Slika 5. Zatvaranje rane korišćenjem slobodnog kožnog translantata po Tiršu

Figure 5. Wound closue using free skin graft after Tiersche

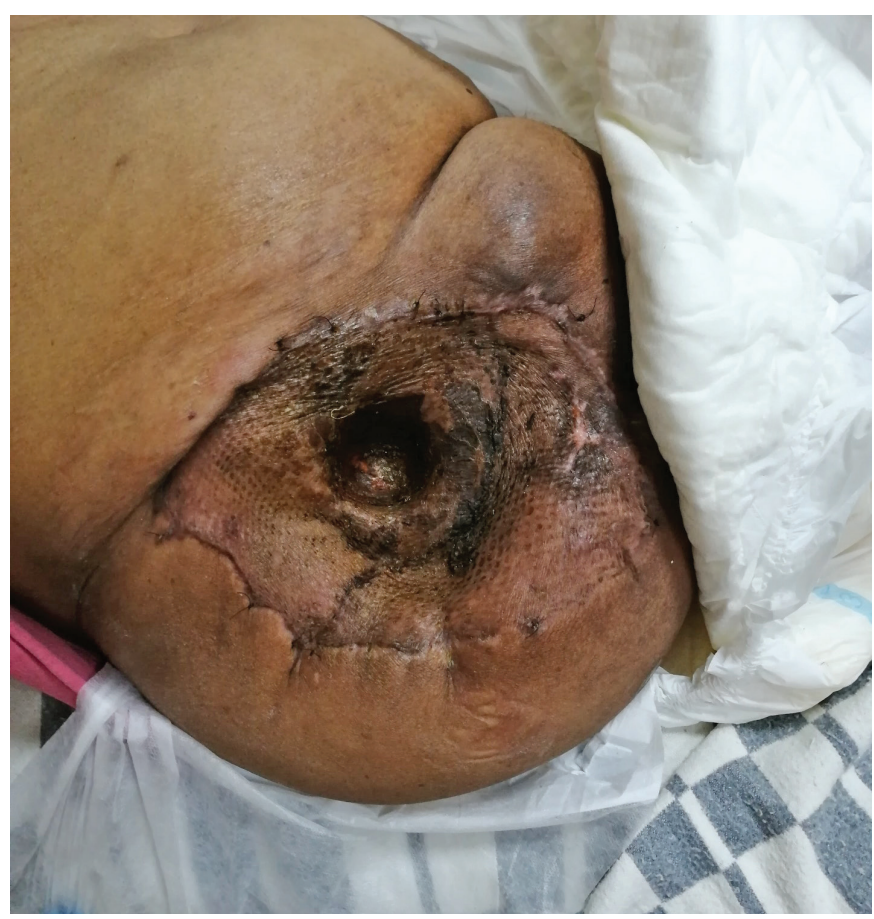

Slika 6. Konačni rezultat nakon šest nedelja

Figure 6. Final result after six weeks 
korišćena je vakuum drenaža pre finalnog zatvaranja rane. Kod svih pacijenata primena antibiotika je bila parenteralna. Edem skrotuma ili labija bila je nezavisna komplikacija, koja, iako neprijatna i nekada bolna, nije bila povezana sa ostalim komplikacijama. Bez poteškoća je tretirana ledenim pakovanjima i elevacijom. Jedini slučaj površinske nekroze bez infekcije i dehiscencije tretiran je produženom negom i previjanjem.

Ograničenja naše studije ogledala su se u malom broju subjekata u uzorku kao i u činjenici da je u pitanju retrospektivna opservaciona studija. U buduće, potrebno je uzeti u obzir i druge faktore kao što su preoperativna terapija zračenjem i hemoterapija.

\section{ZAKLJUČAK}

Komplikacije kod dezartikulacije kuka/hemipelvektomije variraju od beznačajnih do životno ugrožavajućih, produžavajući vreme oporavka i rehabilitacije. Teško je predvideti kod kojih pacijenata će doći do teških komplikacija, pošto to zavisi od više faktora - starosti, opšteg fizičkog stanja, dijagnoze i hirurške tehnike. U ovom trenutku, čak i uz rizik od komplikacija, ovi hirurški zahvati ostaju značajni, posebno za onkološke pacijente, kako je za neke od njih ovo jedina preostala mogućnost.

Sukob interesa: Nije prijavljen.

\section{LITERATURA / REFERENCES}

1. Dillingham TR, Pezzin LE, MacKenzie EJ. Limb amputation and limb deficiency: epidemiology and recent trends in the United States. South Med J. 2002;95(8):875-83.2

2. Loon HE. The past and present significance of hip disarticulation. Artif Limbs. 1957; 4:4-21.

3. Charalampos G, Zalavras MD, Nick Rigopoulos MD, Elke Ahlmann MD, Michael J. Patzakis MD. Hip Disarticulation for Severe Lower Extremity Infections. Clin Orthop Relat Res. 2009; 467:1721-1726.

4. Jain R, Grimer RJ, Carter SR, Tillman RM, Abudu AA. Outcome after disarticulation of the hip for sarcomas. EJSO. 2005; 31:1025-1028.

5. Endean ED, Schwarcz TH, Barker DE, Munfakh NA, Wilson-Neely R, Hyde GL. Hip disarticulation: factors affecting outcome. J Vasc Surg. 1991; 14:398-404.

6. Unruh T, Fisher DF Jr, Unruh TA, Gottschalk F, Fry RE, Clagett GP. Hip disarticulation. An 11-year experience. ArchSurg. 1990; 125(6):791-3.

7. László G, Kullmann L. Hip disarticulation in peripheral vascular disease. Arch Orthop Trauma Surg. 1987; 106(2):126-8.

8. Daigeler A, Lehnhardt M, Khadra A, Hauser J, Steinstraesser L, Langer S. Proximal major limb amputations - a retrospective analysis of 45 oncological cases. World J Surg Oncol. 2009; 7:15.

9. Rodolfo J0, Alexander HM. Emergency incarcerated obturator hernia repair with biologic mesh in a male patient after ipsilateral hip disarticulation: A case report. Int J Surg Case Rep. 2017; 37:41-44.
In our series, all of the patients with wound dehiscence were treated surgically, some multiple times. In some cases, vacuum drainage was used before final surgical wound closure. Parenteral antibiotics were used in all cases. Scrotal/labial edema was an independent complication which, although unpleasant and sometimes painful, was not connected with other complications. It was easily treated with ice packs and elevation. The only case of superficial necrosis without infection and dehiscence was treated with prolonged care and bandaging.

The limitations of the present study were the small number of individuals in the sample and the fact that it was a retrospective observational study. In future, other factors, such as preoperative radiation therapy and chemotherapy, should be taken into account.

\section{CONCLUSION}

Complications in hip disarticulation/hemipelvectomy vary from insignificant to life threatening, prolonging recovery and rehabilitation. It is hard to predict which patients are likely to have severe complications, since these depend on multiple factors - age, general physical condition, diagnosis, and surgical technique. At present, even with the risk of complications, these surgical procedures remain significant, especially for oncological patients, as for some of them this is the last resort.

Conflict of interest: None declared.

10. Senchenkov A, Moran SL, Petty PM, Knoetgen J 3rd, Clay RP, Bite U, et al. Predictors of complications and outcomes of external hemipelvectomy wounds: account of 160 consecutive cases. Ann Surg 0ncol. 2008; 15:355-363.

11. Karakousis $(P$, Emrich LJ, Driscoll DL. Variants of hemipelvectomy and their complications. Am J Surg. 1989; 158:404-8.

12. Apffelstaedt JP, Zhang PJ, Driscoll DL, Karakousis CP. Various types of hemipelvectomy for soft tissue sarcomas: complications, survival and prognostic factors. Surg Oncol. 1995; 4:217-22.

13. Apffelstaedt JP, Driscoll DL, Spellman JE. Complications and outcome of external hemipelvectomy in the management of pelvic tumors. Ann Surg Oncol. 1996; 3:304-9.

14. Adam JS, Darrin JT, Katherine AB, Kristine TH, David AE, Elizabeth BH. Hip Disarticulation for Periprosthetic Joint Infection: Frequency, Outcome, and Risk Factors. J Arthroplasty. 2020 Jun 15; S0883-5403(20)30661-6.

15. Colosimo C, Fredericks C, James RY, John CK, Faran B, Stathis P. Damage control hip disarticulation: two-stage operation with index creation of a large medial flap for the septic hip. Trauma Surg Acute Care Open. 2020 Sep 1; 5(1):e000502.

16. Moura DL, Garruço A. Hip disarticulation - case series analysis and literature review. Rev Bras Ortop. 2017; 3:52(2):154-158.

17. Patera M, Mizera R. Severe Lower Extremity Infections Treated with Hip Disarticulation - Case Series. Acta Chir Orthop Traumatol Cech. 2017; 84(5):396-400. 